\title{
AnAlisis Pengaruh DisPoSisi MATEMATIS, KeMAMPUAN BERPIKIR KREATIF, DAN PERSEPSI PADA KREATIVITAS TERHADAP Kemampuan Pemecahan Masalah Matematis
}

\author{
ANALYSIS EFFECT DISPOSITION MATHEMATICALLY, CREATIVE THINKING \\ Skills and CReativity Of PERCEPtion In Mathematical Problem \\ SOLVING ABILITY
}

\author{
Ali Mahmudi ${ }^{1}$, Bagus Ardi Saputro \\ ${ }^{1}$ FPMIPA, Universitas Negeri Yogyakarta \\ Yogyakarta, 55281, Indonesia \\ ali_uny73@yahoo.com \\ ${ }^{2}$ FIP, Universitas PGRI Semarang \\ Semarang, 50125, Indonesia \\ bagusardisaputro@yahoo.co.id \\ ${ }^{2}$ SPs, Universitas Pendidikan Indonesia \\ Bandung, 40154, Indonesia \\ bagusardisaputro@student.upi.edu
}

\begin{abstract}
Abstrak
Penelitian ini bertujuan untuk menguji pengaruh persepsi pada kreativitas terhadap kemampuan berpikir kreatif; pengaruh disposisi matematis dan kemampuan berpikir kreatif terhadap kemampuan pemecahan masalah matematis. Metode statistika yang digunakan adalah analisis jalur. Hasil pengujian menunjukkan bahwa terdapat pengaruh yang signifikan dari persepsi pada kreativitas terhadap kemampuan berpikir kreatif; terdapat pengaruh yang signifikan dari kemampuan berpikir kreatif dan disposisi matematis terhadap kemampuan pemecahan masalah matematis; terdapat pengaruh tidak langsung dari persepsi pada kreativitas terhadap kemampuan pemecahan masalah matematis.
\end{abstract}

Kata Kunci: disposisi matematis, berpikir kreatif, persepsi pada kreativitas, pemecahan masalah

\begin{abstract}
This study aimed to examine the effect on the perception of creativity to the creative thinking abilities; the effect of the disposition of mathematical and creative thinking abilities to mathematical problem solving ability. Statistical method used is path analysis. The test results indicate that there is significant influence of perception on the creativity of the creative thinking abilities; significant influence on the ability to think creatively and mathematical disposition towards mathematical problem solving ability; There are no direct influence on the perception of the creativity of the mathematical problem solving ability.
\end{abstract}

Keyword: mathematical disposition, creative thinking, the perception of creativity, problem-solving 


\section{Pendahuluan}

Kemampuan berpikir kreatif ini sangat diperlukan siswa dalam memecahkan suatu permasalahan matematika [1]. Karena dalam menyelesaikan menyelesaikan masalah secara berkelompok para siswa akan saling mengajukan ide kreatif mereka, berdiskusi, dan berfikir secara kritis [2]. Siswa berpikir kreatif dalam pemecahan masalah untuk mensintesis berbagai konsep yang digunakan [3], fleksibel dalam memecahkan masalah yang kompleks ([4],[5]), membuat (merumuskan) dan menyelesaikan model matematika serta menafsirkan solusi dari suatu masalah matematika [1], serta memecahkan masalah dengan tekun dan cermat [6]. Sehingga berpikir kreatif dapat berpengaruh terhadap kemampuan pemecahan masalah.

Hasil penelitian Mahmudi menunjukkan bahwa kemampuan berpikir kreatif matematis berasosiasi dengan persepsi terhadap kreativitas [7]. Hal ini dikarenakan sikap terhadap matematika dan persepsi pada kreativitas memang prediktor yang signifikan bagi kreativitas siswa [8]. Sehingga persepsi pada kreativitas dapat berpengaruh terhadap aktivitas berpikir kreatif siswa. Artinya dapat juga persepsi pada kreativitas berpengaruh secara tidak langsung terhadap kemampuan pemecahan masalah matematis siswa.

Mahmudi juga menemukan bahwa kemampuan pemecahan masalah cenderung berasosiasi dengan disposisi matematis [7]. Hal itu karenakan ketika siswa memecahkan masalah, siswa harus percaya diri dalam menggunakan matematika, fleksibel dalam menyelidiki gagasan. Siswa juga harus mempunyai ketekunan, minat yang tinggi, rasa ingin tahu, daya temu, cenderung memonitor dan merefleksi diri sendiri, serta senang menilai dan menghargai peran matematika. Henningsen \& Stein juga menjelaskan bahwa salah satu faktor yang mempengaruhi kerja siswa adalah disposisi belajar siswa [9]. Oleh karena itu disposisi matematis siswa sangat berpengaruh dalam kemampuan pemecahan masalah matematis mereka.

Sehingga dari uraian diatas diperoleh beberapa hubungan kausal antara persepsi pada kreativitas, kemampuan berpikir kreatif, disposisi matematis dan kemampuan pemecahan masalah matematis yang memunculkan beberapa pertanyaan yaitu (1) Apakah persepsi terhadap kreativitas berpengaruh terhadap kemampuan berpikir kreatif? (2) Apakah kemampuan berpikir kreatif dan disposisi matematis berpengaruh terhadap kemampuan pemecahan masalah matematis? (3) Berapa besar pengaruh langsung, tidak langsung, total dan bersama dari variabel persepsi pada kerativitas, kemampuan berpikir kreatif, dan disposisi matematis terhadap kemampuan pemecahan masalah matematis?

\section{Pengembangan Hipotesis}

Hipotesis

1. Persepsi terhadap kreativitas $\left(X_{3}\right)$ mempengaruhi secara positif terhadap kemampuan berpikir kreatif $\left(\mathrm{X}_{2}\right)$

2. Disposisi matematis $\left(\mathrm{X}_{1}\right)$, kemampuan berpikir kreatif $\left(\mathrm{X}_{2}\right)$, dan persepsi terhadap kreatifitas $\left(\mathrm{X}_{3}\right)$, baik secara bersama maupun individual mempengaruhi kemampuan pemecahan masalah matematis (Y) 


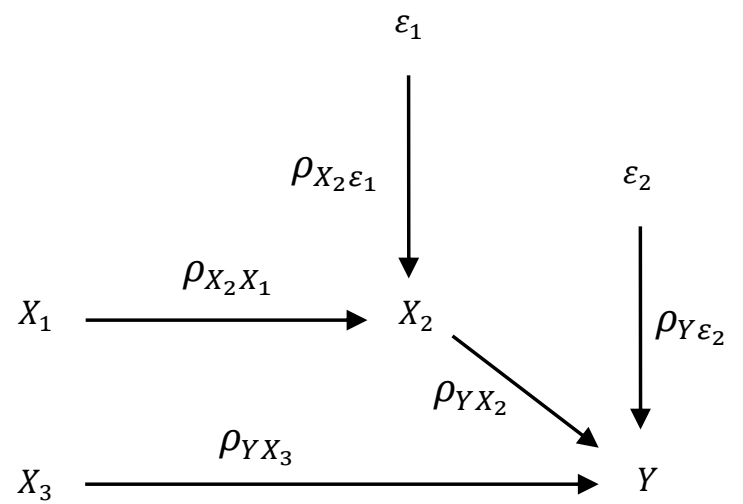

Gambar 1. Diagram Jalur Lengkap

Persamaan struktural dari diagram jalur pada Gambar 1 adalah

$$
\begin{gathered}
X_{2}=\rho_{X_{2} X_{1}} X_{1}+\rho_{X_{2} \varepsilon_{1}} \varepsilon_{1} \\
Y=\rho_{Y X_{2}} X_{2}+\rho_{Y X_{3}} X_{3}+\rho_{Y \varepsilon_{2}} \varepsilon_{2}
\end{gathered}
$$

Keterangan :

$X_{1}=$ persepsi pada kreatifitas

$X_{2}=$ kemampuan berpikir kreatif

$X_{3}=$ disposisi matematis

$Y=$ kemampuan pemecahan masalah matematis

\section{Metode}

Penelitian ini menggunakan pendekatan kuantitatif. Dalam penelitian ini peneliti menggunakan analisis jalur, yang pengolahan datanya menggunakan SPSS 16. Populasi dalam penelitian ini adalah seluruh siswa dari dua SMP di Kota Yogyakarta. Dari masing - masing sekolah dipilih satu kelas sebagai sampel. Pemilihan kelas ini tidak dilakukan secara acak.

Jenis data yang digunakan dalam penelitian ini adalah data sekunder yang diperoleh dari Disertasi Mahmudi yaitu berupa data mentah yang meliputi data kemampuan pemecahan masalah matematis, data disposisi matematis, data kemampuan berpikir kreatif, dan data persepsi terhadap kreativitas kelas kontrol tinggi dan sedang [7]. Variabel dalam penelitian ini meliputi variabel eksogen dan endogen. Variabel eksogennya adalah disposisi matematis, dan persepsi terhadap kreativitas. Sedangkan variabel endogennya adalah kemampuan berpikir kreatif, dan kemampuan pemecahan masalah.

Agar pemahaman tentang variabel penelitian tidak memberikan salah tafsir, maka didefinisikan secara operasional sebagai berikut:

1. Kemampuan pemecahan masalah matematis meliputi aspek pemehaman yaitu mengidentifikasi data atau informasi yang diperlukan untuk menyelesaikan masalah dan menyusun model matematis dari masalah yang akan diselesaikan, (2) penggunaan strategi dan prosedur mencakup kemampuan memilih dan menggunakan strategi pemecahan masalah, dan melakukan prosedur matematis untuk menyelesaikan masalah, (3) komunikasi mencakup kemampuan memberikan penjelasan terhadap strategi, konsep - konsep terkait, dan prosedur matematis yang dilakukan untuk menyelesaikan masalah, menggunakan representasi, istilah atau notasi matematis yang sesuai, dan memaknai atau mengkomunikasikan solusi.

2. Kemampuan berpikir kreatif meliputi aspek (1) kelancaran yaitu 
menyelesaikan masalah dan memberikan banyak jawaban terhadap masalah tersebut; atau memberikan banyak contoh atau pernyataan terkait konsep atau situasi matematis tertentu, (2) keluwesan yaitu kemampuan menggunakan beragam strategi penyelesaian masalah, atau memberikan beragam contoh atau pernyataan terkait konsep atau situasi matematis tertentu, (3) kebaruan meliputi kemampuan menggunakan strategi yang bersifat baru, unik, atau tidak biasa untuk menyelesaikan masalah, atau memberikan contoh atau pernyataan yang bersifat baru, unik atau tidak biasa.

3. Disposisi matematis adalah dorongan, kesadaran atau kecenderungan yang kuat untuk belajar matematika serta berperilaku positif dalam menyelesaikan masalah matematis yang meliputi aspek (1) kepercayaan diri, (2) kegigihan atau ketekunan, (3) fleksibilitas dan keterbukaan berpikir, (4) minat dan keingintahuan,dan (5) kecenderungan untuk memonitor proses berpikir dan kinerja sendiri.

4. Persepsi terhadap kreativitas adalah cara pandang terhadap kreativitas dan pengembanganya yang meliputi aspek

(1) potensi kreatif, (2) lingkup kreativitas, (3) karakteristik ide kreatif, (4) karakteristik individu kreatif, dan (5) pengebangan kreativitas.
III. Hasil dan Pembahasan

Tabel 1. Koefisien Struktur 1

\begin{tabular}{cccccc}
\hline Variabel & B & $\begin{array}{c}\text { Std. } \\
\text { Eror }\end{array}$ & Beta & t & Sig \\
\hline Konstanta & 13.97 & 9.821 & & 1.422 & .160 \\
& 0 & & & & \\
\hline $\begin{array}{c}\text { Persepsi } \\
\text { pada }\end{array}$ & .440 & .235 & .233 & 1.869 & .066 \\
Kreativita & & & & & \\
s & & & & & \\
\hline
\end{tabular}

Dependent Variable: Kem_Berpikir_Kreatif

Dari Tabel 1 koefisien jalur Persepsi terhadap kreativitas $\left(\rho_{X_{2} X_{1}}\right)=0.233$ $(t=1.869 ; P=0.066) \quad$ secara statistik signifikan. Besarnya koefisien determinasi $\left(X_{1}\right)$ terhadap $\left(X_{2}\right)$ adalah $R_{X_{3} X_{2}}^{2}=0.054$. Besarnya pengaruh variabel lain diluar $X_{1}$ terhadap $X_{2}$ adalah $\rho_{X_{2} \varepsilon_{1}}=\sqrt{1-0.054}=$ 0.973 . Dengan demikian diagram jalur sub - struktur 1 adalah

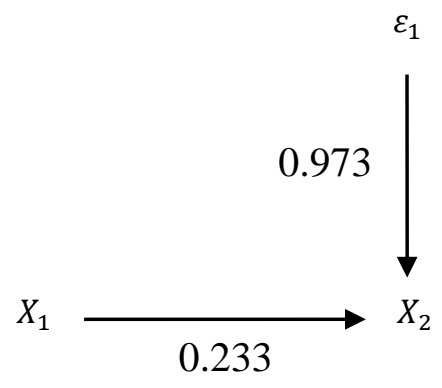

Gambar 2. Hubungan Kausal $X_{1}$ ke $X_{2}$

Tabel 2. Koefisien Struktur 2.

\begin{tabular}{cccccc}
\hline Variabel & B & $\begin{array}{c}\text { Std. } \\
\text { Eror }\end{array}$ & Beta & t & Sig \\
\hline Konstanta & - & 16.317 & & - & .277 \\
& 17.914 & & & 1.098 & \\
\hline $\begin{array}{l}\text { Kemampuan } \\
\text { Berpikir } \\
\text { Kreatif }\end{array}$ & .526 & .188 & .326 & 2.796 & .007 \\
$\begin{array}{l}\text { Disposisi } \\
\text { Matematis }\end{array}$ & .465 & .201 & .270 & 2.320 & .024 \\
Dependent Variable: Kem_Pemecahan_Masalah & \\
\end{tabular}


Dari Tabel 2 diperoleh bahwa Koefisien jalur kemampuan berpikir kreatif ke kemampuan pemecahan masalah $\left(\rho_{Y X_{2}}\right)=$ $0.326 \quad(t=2.796 ; P=0.007) \quad$ dan koefisien jalur disposisi matematis terhadap kemampuan pemecahan masalah $\left(\rho_{Y X_{3}}\right)=0.270 \quad(t=2.320 ; P=0.024)$ secara statistik. Besarnya koefisien determinasi kemampuan berpikir kreatif dan disposisi matematis terhadap kemampuan pemecahan masalah adalah $R_{Y X_{2} X_{3}}^{2}=0.208$

Besarnya pengaruh variabel lain diluar kemampuan berpikir kreatif dan persepsi terhadap kreativitas terhadap kemampuan pemecahan masalah adalah $\rho_{Y \varepsilon_{2}}=$ $\sqrt{(1-0.208)}=0.8899$. Dengan demikian, diagram jalur sub struktur 2 mengalami perubahan sehingga demikian

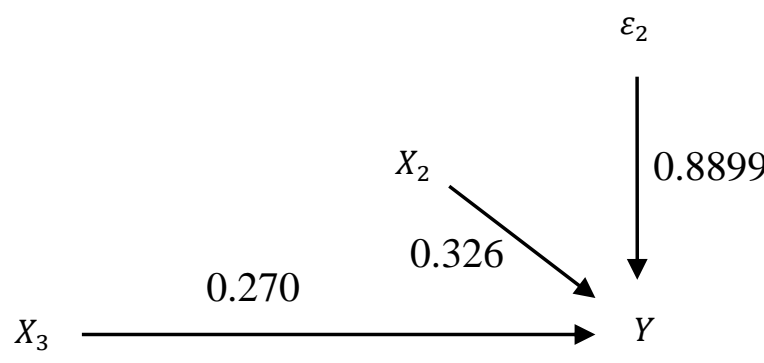

Gambar 3. Hubungan Kausal $X_{2}, X_{3}$ ke $Y$

Berdasarkan pengujian koefisien jalur, baik dalam sub - struktur 1 maupun sub struktur 2, maka dapat dikemukakan diaram koefisien jalur lengkap yang menggambarkan hubungan kausal empiris antar variabel penelitian $X_{1}, X_{2}, X_{3}$ dan $Y$ sebagaimana ditampilkan pada Gambar 4 berikut:

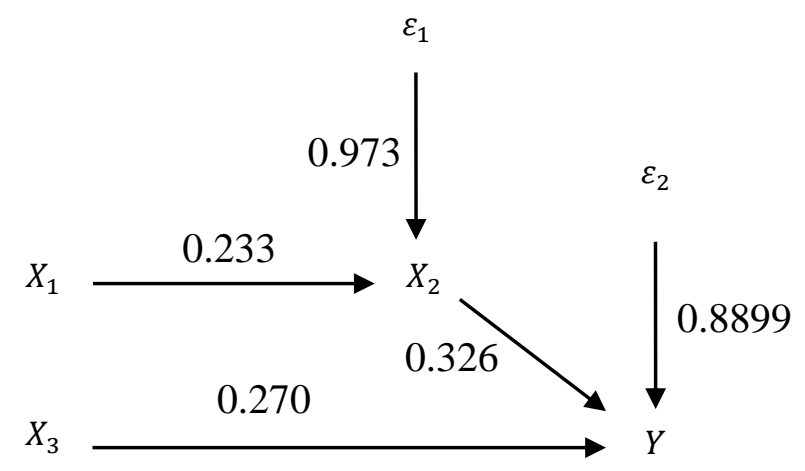

Gambar 4. Hubungan Kasual antara $X_{1}, X_{2}, X_{3}$ dan Y

Hubungan ini dinyatakan dalam persamaan struktural

$$
\begin{gathered}
X_{2}=0.233 X_{1}+0.973 \varepsilon_{1} \\
Y=0.326 X_{2}+0.270 X_{3}+0.8899 \varepsilon_{2}
\end{gathered}
$$

Karena dalam proses trimming tidak ada variabel yang dikeluarkan maka disimpulkan bahwa, model sebagaimana diragakan pada Gambar 4 fit sempurna dengan data.

\section{Kesimpulan}

Berdasarkan keseluruhan analisis data, dapat dikemukakan bahwa:

1. Pengaruh persepsi pada kreativitas $\left(X_{1}\right)$ terhadap kemampuan berpikir kreatif $\left(X_{2}\right)$ adalah $5.4 \%$ dan sisanya yaitu $94.6 \%$ merupakan pengaruh variabel lain di luar persepsi pada kreativitas $\left(X_{1}\right)$.

2. Pengaruh kemampuan berpikir kreatif $\left(X_{2}\right)$ dan disposisi matematis $\left(X_{3}\right)$ terhadap kemampuan pemecahan masalah matematis $(Y)$ masing masing sebesar $10.63 \%$ dan $7.29 \%$. 
3. Pengaruh kemampuan berpikir kreatif $\left(X_{2}\right)$ dan disposisi matematis $\left(X_{3}\right)$ terhadap kemampuan pemecahan masalah matematis $(Y)$ secara bersama sebesar $20.8 \%$,

4. Pengaruh variabel lain diluar kemampuan berpikir kreatif $\left(X_{2}\right)$ dan disposisi matematis $\left(X_{3}\right)$ terhadap kemampuan pemecahan masalah matematis $(Y)$ sebesar $79.2 \%$.

5. Persepsi pada kreativitas $\left(X_{1}\right)$ mempengaruhi kemampuan pemecahan masalah matematis $(Y)$ secara tidak langsung, yaitu melalui kemampuan berpikir kreatif $\left(X_{2}\right)$. Besar pengaruh secara tidak langsung yang terjadi melalui kemampuan berpikir kritis $\left(X_{2}\right)$ adalah $(0.233)(0.326)=0.075958$. Dengan demikian, pengaruh total persepsi terhadap kreativitas $\left(X_{1}\right)$ ke kemampuan pemecahan masalah matematis $(Y)$ adalah $7.59 \%$.

Walaupun pengaruh kemampuan berpikir kreatif dan disposisi matematis terhadap kemampuan pemecahan masalah matematis signifikan, perlu juga mempertimbangkan pengaruh variabel lain yang lebih besar.

\section{Daftar Pustaka}

[1] A. A. Saefudin, "Pengembangan Kemampuan Berpikir Kreatif Siswa dalam Pembelajaran Matematika dengan Pendekatan Pendidikan Matematika Realistik Indonesia (PMRI)", Al Bidayah, 4(1), 2014.

[2] K. H. Roh, "Problem-based learning in mathematics", ERIC Clearinghouse for Science Mathematics and
Environmental Education, 2004-3, 2003.

[3] J. B. N. Nakin, Creativity and Divergent Thinking in Geometry Education, Disertasi pada University of South Africa, 2003.

[4] H. Park, The Effects of Divergent Production Activities with Math Inquiry and Think Aloud of Students with Math Difficulty, Disertasi pada Texas A \& M. University, 2004.

[5] K. L. Alexander, Effects Instruction in Creative Problem Solving on Cognition, Creativity, and Satisfation among Ninth Grade Student in an Introduction to World Agricultural Science and Technology Course, Disertasi pada Faculty of Texas Tech University, 2007.

[6] W. Y. Hwang, et al, "Multiple Representation Skills and Creativity Effects on Mathematical Problem Solving using a Multimedia Withboard System", Dalam Educational Technology \& Society Journal, 10(2), 191 - 212, 2007.

[7] A. Mahmudi, Pengaruh pembelajaran dengan Strategi MHM Berbasis Masalah Terhadap Kemampuan Berpikir Kreatif, Kemampuan Pemecahan Masalah, dan Disposisi Matematis, Serta Persepsi Terhadap Kreativitas, Disertasi SPS UPI, Tidak diterbitkan, 2010.

[8] E. L. Mann, Mathematical Creativity and School Mathematics: Indicators of Mathematical Creativity in Middle School Students, Disertasi pada University of Connecticut, 2005. 
[9] M. Henningsen \& M. K. Stein, 'Supporting Student' High-Level Thinking, Reasoning, and Communication in Mathematics", Dalam Sowder dan Schappelle (Eds), Lesson Learned from Research, Reston, V.A: NCTM, 2002.

\section{Riwayat Hidup PenUlis}

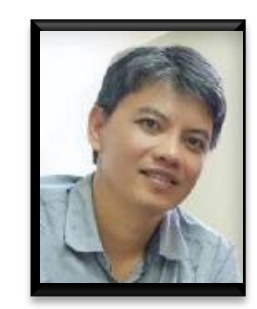

Dr. Ali Mahmudi, S.Pd., M.Pd. Staf pengajar di Universitas Negeri Yogyakarta. Studi S1 bidang pendidikan matematika di UNS Surakarta lulus tahun 1997, S2 bidang pendidikan matematika di UNESA Surabaya lulus tahun 2003, dan S3 bidang pendidikan matematika di Universitas Pendidikan Indonesia lulus tahun 2010.

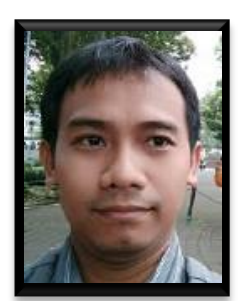

Bagus Ardi Saputro, S.Pd., M.Pd. Staf pengajar di Universitas PGRI Semarang. Studi S1 bidang pendidikan matematika di IKIP PGRI Semarang lulus tahun 2009, S2 bidang pendidikan matematika di Universitas Pendidikan Indonesia lulus tahun 2011, dan sedang S3 bidang pendidikan matematika di Universitas Pendidikan Indonesia. 
